deficiency or an abnormal immunological response has been found. The unexpected and intriguing finding of Willman and colleagues was that all 10 lesions from patients with Langerhans' cell histiocytosis whom they studied contained clonal populations of cells, with the proportion of clonal cells corresponding to the proportion of lesional Langerhans-like cells, whether from solitary lesions or extensive multisystem disease. The clonal nature of Langerhans' cell histiocytosis from the initiation of the disease process suggests that this is a true tumour and not a non-specific condition that predisposes to the development of neoplasia. The initial lesion may provide the necessary clues to the primary molecular event leading to tumorigenesis. Yu et al last year reported similar findings in tissues enriched by flow sorting of CD1a positive cells from three patients. ${ }^{11}$ Sequential studies, to show that the "clonality" pattern is constant throughout the course of the disease, are needed, but these observations still provide the first solid clue to defining the aetiology of the condition in 100 years.

\section{Somatic mutation}

The hypothesis that Langerhans' cell histiocytosis arises from somatic mutation of DNA in a normal Langerhans' cell or precursor cell, leading to a neoplastic phenotype, must now be seriously considered, even though studies of clonality have not shown mutation. A single mutation that provides a growth advantage does not necessarily equate with malignancy, but the increased proliferation of cells may predispose to additional somatic mutations ${ }^{12}$ and evolution in some cases to cancer.

Throughout this process the abnormal Langerhans'-like cells would retain the same $\mathrm{X}$ linked clonal marker. Varying clinical outcomes would depend on the number of mutations acquired, possibly on the role of immune surveillance and on the micro environment where the mutated cells are sited or to which they migrate. Additional gene mutations might cause clonal evolution of the disease from a benign to a more malignant invasive form.

Alone, monoclonality is necessary but not sufficient to define neoplasia. Benign parathyroid adenomas may be clonal, ${ }^{13}$ and lymphoproliferation associated with immunodeficiency may move through a benign polyclonal prolif- erative disease to a monoclonal process, as shown by rearrangements of immunoglobulin heavy chains, eventually progressing to a malignant phenotype. ${ }^{14}$

Molecular technologies for examining complex genome changes, such as fluorescent in situ hybridisation and comparative genome mapping, ${ }^{15}$ are now at a stage at which they could be applied to Langerhans' cell histiocytosis and provide clues to the molecular pathology of this disorder. Willman and her colleagues have presented a powerful demonstration of the use of clonal analysis and an important direction for future research into Langerhans' cell histiocytosis. ${ }^{6}$ Application of $\mathrm{X}$ linked analysis to other disorders of histiocytes will be informative. In research to improve the prediction of prognosis and to suggest treatments samples of female tissue will be at a premium.

FINBARR E COTTER

Haematology and Oncology Unit, Senior lecturer in haematology and oncology

Institute of Child Health,

London WC1N 1EH

JON PRITCHARD

Great Ormond Street Hospital,

Consultant in paediatric oncology

London WC1N 3JH

1 Cotter FE. Gene rearrangement and minimal residual disease in lympho proliferative disorders. In Newland A, Armitage J, Burnett A, Keating A, eds. Haematological oncology. Cambridge: Cambridge University Press, 1991:1:145-72.

2 Miteleman F, Kaneko Y, Trent J. Report of committee on chromosome changes in neoplasis. Cytogenet Cell Genet 1991;58:1053-79.

3 Fialkow PJ. The origin and development of human tumors studied with cell markers. N Engl $\mathcal{F}$ Med 1974;289:26-35.

4 Vogelstein B, Fearon ER, Hamilton SR, Preisinger AC, Willard HF, Michelson AM, et al. Clonal analysis using recombinant DNA probes from the X-chromosome. Cancer Res 1987;47:4806-13.

5 Busque L, Zhu J, De Hart D, Griffith B, Willman C, Carroll R, et al. An expression based clonality assay at the human androgen-receptor locus (HUMARA) on chromosome X. Nucl Acids Res 1994;22:697-8.

6 Willman CL, Busque L, Griffith BB, Favara BE, McLain KL, Duncan MH, et al. Langerhans'-cell histiocytosis (histiocytosis X) - a clonal proliferative disease. N Engl f Med 1994;331:154-60.

7 Langerhans P. Uber die Nerven der menschlichen Haut. Virch Archiv Pathol Anat 1868;44:325-7.

8 Favara BE. Histiocytosis syndromes: classification, diagnostic features and current concepts. Leuk ara BE. Histiocytosis symd

Mierau GW, Wills EJ, Steele PO. Ultrastructural studies in Langerhans cell histiocytosis: a search for evidence of vital etiology. Pediatr Pathol (in press).

10 McClain K, Weiss RA. Viruses and Langerhans cell histiocytosis: is there a link? Br $\mathcal{f}$ Cancer 1994;70:S34-6.

11 Yu RC, Chu C, Buluwela L, Chu AC. Clonal proliferation of Langerhans cells in Langerhans cell histiocytosis. Lancet 1994;343:767-8.

12 Knudson AGJ. Hereditary cancer, oncogenes and antioncogenes. Cancer Res 1985;45:1437-43.

13 Arnold A, Staunton CE, Kim HG, Gaz RD, Kronenberg HM. Monoclonality and abnormal parathyroid hormone genes in parathyroid andenomas. $N$ Engl f Med 1988;318:658-62.

14 Cotter FE. Molecular pathology of lymphomas. Cancer Surveys 1993;16:157-73.

15 Kallioniemi O-P, Kallioniemi A, Piper J, Isola J, Waldman FM, Gray JW, et al. Optimizing comparative genomic hybridisation for analysis of DNA sequence copy number changes in solid tumors. Genes Chromosom Cancer 1994;10:231-43.

\title{
Nutrition and lung health
}

\section{Should people at risk of chronic obstructive lung disease eat more fruit and vegetables?}

In striking contrast to the relation between diet and cardiovascular disease, the relation between diet and lung disease has not received much attention. Standard texts on nutrition make little or no reference to the respiratory system. ${ }^{1}$ Two reasons help to explain this relative neglect. Firstly, the most common fatal diseases of the respiratory system-lung cancer and chronic obstructive pulmonary disease-are so clearly related to tobacco smoking that other factors have had little scrutiny. Secondly, even in those respiratory diseases in which nutrition is believed to play an important part (for example, cystic fibrosis and emphysema), the relation between nutrition and the disease is not directly causal. This has made investigation of the place of nutrition in the pathological process unattractive. Interesting new evidence is, however, beginning to emerge from sources as varied as molecular biology laboratories and epidemiological units. This suggests that a relation may exist between intake of certain dietary elements and lung disease-and that the links may have a practical importance.

In 1990 an analysis of data from a representative sample of adults in the United States suggested that a high dietary intake and a raised serum concentration of vitamin $C$ had a protective effect against respiratory symptoms. ${ }^{2}$ Independent of cigarette smoking, an inverse relation was shown between bronchitis diagnosed by a doctor and dietary intake of vitamin C. Strachan et al compared 1502 non-smokers and 1357 smokers with no history of respiratory disease and found that consumption of fresh fruit in winter (and by implication habitual consumption of fruit) was related to ventilatory function not only in current smokers but also in lifelong 
non-smokers. ${ }^{3}$ After adjustment for differences in anthropometric measures, socioeconomic status, and smoking habits the forced expiratory volume in one second in the group with a low intake of fruit was about $80 \mathrm{ml}$ less than that in the group with a high intake.

A cross sectional study of over 2500 adults in Nottinghamshire showed that not only was the forced expiratory volume in one second directly related to habitual intake of vitamin C (after adjustment for smoking habits) but also that this effect of vitamin $\mathrm{C}$ on the lungs was greater in the older age group, suggesting that the vitamin had a protective effect. ${ }^{4}$ More recently, analysis of the data collected for an earlier national nutrition study in the United States has lent further support to this view. ${ }^{5}$ An examination of the relation between dietary n-3 polyunsaturated fatty acids and chronic obstructive pulmonary disease associated with smoking concluded that a high dietary intake of this fatty acid may protect cigarette smokers against the disease. ${ }^{6}$ These were cross sectional studies, but in a longitudinal study a group of Dutch investigators examined the relation between diet and the incidence of chronic non-specific lung disease (a collective term embracing asthma, bronchitis, and emphysema) over 25 years and found that after adjustment for confounding factors fruit intake was inversely related to the incidence of lung disease. $^{7}$

In the case of atopic asthma, studies have mostly looked at the dietary sodium intake. This is explained by two observations made in the mid-1980s-that the response of the airways to histamine correlates with the intake of sodium 8 and that regional mortality from asthma among men and children is strongly related to purchases of table salt.' ${ }^{9}$ Later studies of this relation have, however, yielded conflicting results, and recently the dietary intake of magnesium has been shown to have an independent, beneficial influence on lung function, airway responsiveness, and wheezing in a general population. ${ }^{10}$ The investigators suggested that the relation found between dietary sodium and asthma might have resulted from confounding between the intakes of sodium and magnesium. Dietary factors-in particular selenium as an essential component of the antioxidant glutathione peroxidase-have also been implicated in non-atopic asthma. ${ }^{11}$

\section{Antioxidants again?}

The results of these community based studies fit quite well with the current theories about the pathogenesis of obstructive lung disease. Almost certainly, tissue damage in obstructive lung disease is an inflammatory phenomenon related to damage mediated by oxidants. ${ }^{12}$ Antioxidant enzyme activity is increased in the alveolar macrophages of young asymptomatic smokers, ${ }^{13}$ but similar cells from elderly current smokers show decreased activity and a profound oxidant-antioxidant imbalance. ${ }^{14}$ Lung damage leading to obstructive lung disease seems, therefore, to result from unopposed oxidant activity, which explains why fresh fruit and fish oils-with their high antioxidant and anti-inflammatory activity—offer protection against such damage.

One of the puzzles for respiratory physicians is that, while most patients with chronic obstructive pulmonary disease are smokers, relatively few smokers actually develop severe lung disease. ${ }^{15}$ Some epidemiological studies have pointed to factors related to social class (but unrelated to smoking) that may determine susceptibility to lung disease. ${ }^{16}$ The studies reviewed in this editorial suggest that differences in a tendency to develop obstructive lung disease may be related to diet and in particular the consumption of antioxidant vitamins.

So might a carefully chosen diet protect against obstructive lung disease? And should patients at risk of developing the disease-such as smokers and those with a family history of asthma-be advised to take supplements of appropriate antioxidant vitamins or minerals? Only carefully designed prospective studies (such as the one on antioxidant vitamin supplements and cancer ${ }^{17}$ ) can answer these questions. Mere association does not imply causation, and all the studies cited suggest no more than an association. Most of the researchers took care to avoid results being vitiated by well recognised confounding factors (age, smoking, energy intake, socioeconomic status), but other factors, including genetic ones, might have an important bearing on susceptibility to lung disease.

There is as yet no evidence bridging the gulf between the community based studies and laboratory based studies to show that decreased habitual consumption of antioxidant vitamins is accompanied by failure of antioxidant defence mechanisms in the lung. And, more importantly, antioxidants given as supplements may not have the same effect as antioxidants obtained from natural sources. ${ }^{1}$ Indeed, the use of antioxidant vitamin supplements has sometimes been associated with harmful side effects. ${ }^{17}$

The most effective advice that can be given to promote lung health still remains a simple "don't smoke"-but evidence is accumulating that this may soon be extended to "don't smoke; and eat plenty of fresh fruit and vegetables."

M K SRIDHAR Research fellow

Departments of Human Nutrition and Respiratory Medicine,

University of Glasgow,

Glasgow G31 2ER

1 James WPT, Garrow JS, eds. Human nutrition and dietetics. Edinburgh: Churchill Livingstone, 1993.

2 Schwartz J, Weiss ST. Dietary factors and their relationship to respiratory symptoms: NHANES II. $A m \mathcal{F}$ Epidemiol 1990;130:67-76.

3 Strachan DP, Cox BD, Erzinclioglu SW, Eurof Walters D, Whichelow MJ. Ventilatory function and winter fresh fruit consumption in a random sample of British adults. Thorax 1991;46:624-9.

4 Britton J, Pavord I, Richards K, Knox A, Wahedna I, Wisniewski A, et al. The effects of dietary antioxidants on lung function in the general population. Am Rev Respir Dis 1993;147:369.

5 Schwartz J, Weiss ST. Relationship between dietary vitamin C intake and pulmonary function in the first national health and nutrition examination survey (NHANES 1). Am $f$ Clin Nutr 1994;59:110-4.

6 Shahar E, Folsom AR, Melnick SL, Tockman MS, Comstock GW, Gennaro V, et al for the Atherosclerosis Risk in Communities Study Investigators. Dietary n-3 polyunsaturated fatty acids and smoking related chronic obstructive pulmonary disease. $N$ Engl $f$ Med 1994;331: acids and

7 Meidema I, Feskens EJM, Heederik D, Kromohout D. Dietary determinants of long-term incidence of chronic nonspecific lung diseases. The Zutphen Study. Am $\mathcal{J}$ Epidemiol 1993;138: inciden $37-45$.

8 Burney PGJ, Britton JR, Chinn S, Tattersfield AE, Platt HS, Papacosta AO, et al. Response to inhaled histamine and 24 hour sodium excretion. BMF 1986;292:1483-6.

9 Burney PGJ. A diet rich in sodium may potentiate asthma: epidemiologic evidence for a new hypothesis. Chest 1987;91(suppl):143-8S.

10 Britton J, Pavord I, Richards K, Wisniewski A, Knox A, Lewis S, et al. Dietary magnesium, lung function, wheezing, and airway hyperreactivity in a random adult population sample. Lance 1994;344:357-62.

11 Begishvili B, Doull IJM, Beasley R, Holgate ST. Relation of selenium and glutathione peroxidase with atopy and bronchial hyperreactivity in adults and children. Thorax 1993;48:1082P.

2 Heffner JE, Repine JE. Pulmonary strategies of antioxidant defence. Am Rev Respir Dis 1989;140:531-54

13 Hoidal JR, Fox RB, Lemarbe PA, Perri R, Repine JE. Altered oxidative metabolic responses in vitro of alveolar macrophages from asymptomatic cigarette smokers. Am Rev Respir Dis 1981; 123:85-9.

14 Kondo T, Tagami S, Yoshioka A, Nishimura M, Kawakami Y. Current smoking of elderly men reduces antioxidants in alveolar macrophages. Am $\mathcal{F}$ Respir Crit Care Med 1994;149:178-82.

15 Pride NB. Chronic obstructive pulmonary disease. Epidemiology, aetiology and natural history. In: Brewis RAL, Gibson GJ, Geddes DM, eds. Respiratory medicine. London. Baillière Tindall, 1990:478-9.

16 Burr ML, Holliday RM. Why is chest disease so common in South Wales? Smoking, social class and lung function: a survey of elderly men in two areas. I Epidemiol Community Health 1987;41 140-4.

17 Alpha-Tocopherol, Beta Carotene Cancer Prevention Study Group. The effect of vitamin E and beta carotene supplementation on the incidence of lung cancer and other cancers in smokers. NEngl F Med 1994;330:1029-35.

18 Herbert V. The antioxidant supplement myth. Am f Clin Nutr 1994;60:157-8. 